a symbol of youth, summer is the stage of the highest peak of power and energy, autumn is an adulthood and winter is the old age and death).

So, the noticeable thing in the novel is the accentuation P. Craluk's appeal to the representation of nature, especially to the various types of the landscapes and their particular elements. The main task of such method we see in the author's desire to represent the inner world of main character. In other word, the landscape is an indirect shape of the psychologism. For achieving of this task, the writer uses a lot of methods (visual, phonic, skinny, olfactory and taste sensations, coloristics, comparison).

\title{
References:
}

1. V'jazovsjkyj, Gh. A. (1987). Svit khudozhnjoji literatury [World of Fiction]. Kyiv : Dnipro. (in Ukrainian)

2. Kraljuk, P. M. (2014). Shestydnev, abo Korona domu Ostrozjkogho [Shestydnev, or the Crown of Ostroh`s House]. Synopsys [Synopsis]. Kyiv : Jaroslaviv Val, pp. 123-341. (in Ukrainian)

3. Lotman, Yu. M. (1996). «Sady» Delilya v perevode Voyeykova i ikh mesto v russkoy literature [«Gardens» of Delilah translated by Voeikov and their place in Russian literature]. $O$ poetakh $i$ poezii [About poets and poetry]. Sankt-Peterburg : «Iskusstvo-SPB», pp. 468-487. (in Russian)

4. Sergeyeva, Yu. M. (2017). Intrapersonal'naya kommunikatsiya: psikhologicheskiy i lingvisticheskiy aspekty [Intrapersonal communication: psychological and linguistic aspects]. Moskva : MPGU. (in Russian)

5. Ufimtseva, N. V., Cherkasova, G. A., Karaulov, Yu. N., \& Tarasov Ye. F. (2004). Slavyanskiy assotsiativnyy slovar': russkiy, belorusskiy, bolgarskiy, ukrainskiy [Slavic associative dictionary: Russian, Belarusian, Bulgarian, Ukrainian]. Moskva. (in Russian)

\section{TYPES OF LINGUISTIC ENANTIOSEMY}

\section{Emiliia Nikolaiesku ${ }^{1}$}

DOI: https://doi.org/10.30525/978-9934-588-11-2_46

The appeal to enantiosemy is caused by the fact that modern discourse demonstrates its common usage. Discursive errors are often caused by wordplay and enantiosemy for specific effect. On the one hand, it is a mistake of meaning interpretation, on the other hand, it is made by the author intentionally.

Enantiosemy is a lexical-semantic phenomenon in which one polysemantic token has structurally opposite semes. It is evident both in language and in speech on the basis of opposition, contrast in the framework of various differential semes as part of sememes, but there always must be one common seme, attests to the word polysemy such as: Ukrainian позичати - 1) to borrow something from someone; 2) to lend something to someone; French aucun - 1) nobody, nothing; 2) someone, anyone, everyone; English sibling - a brother or a sister. Enantiosemy makes many problems

\footnotetext{
${ }^{1}$ Educational and Scientific Center for Language Training of National Academy of Security Service of Ukraine, Ukraine
} 
that could be attacked by the modern approaches of cognitive science, pragmatics, psychology, etc. Therefore, today it could be considered as a discursive and cognitive phenomenon.

The enantiosemy phenomenon has recently been the subject of linguo-semantic investigations. For the first time, this linguistic phenomenon was described by V. Shertsl in $1883-1884$ in the work «On words with opposite meanings (or on the so-called enantiosemy)». He gave the name to this phenomenon: from the Greek «enantios»-means the opposite and «sema»- means the sign. Some aspects of this problem in different linguistic cultures were studied at one time by many scientists (K. Abel, L. Bezsonova, L. Bulakhovskyi, V. Chervonozhka, T. Fedorenko, B. Haneev, Ya. Helblu, V. Ivashchenko, R. Maier, T. Nedelke, I. Pete, V. Prokhorova, O. Shmelov, I. Smushchynska, O. Taranenko and others), however, it still requires a thorough and scrupulous analysis.

V. Shertsl himself considered enantiosemy to be an unproductive phenomenon, a lack of language to contend with, and «the more ancient the language is and the more primitive the people are, the more common this phenomenon is» [2, p. 259]. In particular, the linguist pointed out that this phenomenon is extremely rare and inhibits language in the way of its development. However, modern European languages, including French, testify to the opposite.

The sememes that form the enantiosemy are different: 1) one is used nowadays, the other is outdated, so the usage ambit was narrowed; 2) both semes are actively used in the language; 3) both semes are outdated. Although enantiosemy, in fact, is considered as «anachronism», an element of ancient languages, the French language inherited this phenomenon from Latin, where it was also quite often observed, for example: Latin affectio (Frech affection) - 1) devotion, love, tenderness; 2) ailment, illness; Latin certus (Frech certain) - 1) defined, installed; 2) of some kind, certain. When analyzing a historical text, for example, we have to take into account the meaning that was before, but not the modern.

Therefore, it raises the problem of understanding the meaning of a statement that largely depends on the context (broad / narrow linguistic / extralinguistic), so enantiosemy is often non-language, but speech, and even discursive.

Today our matter demonstrates the existence of different enantiosemy types. In our work, we use a classification developed by I. Smushchynska based on a dialectical principle of opposition. According to the researcher, the French enantiosemes can be divided into the following types: 1) linguistic - speech enantiosemy; 2) complete incomplete; 3 ) absolute - relative; 4) logical - affective; denotative - connotative; 5) substantive, adjective, verb, adverbial, pronominal, exclamatory; 6) lexical (lexemic) - phraseological; 7) lexico-semantic, syntactic, discursive; 8) lexical grammatical; 9) stylistic (is peculiar for both literary and colloquial French language, term systems, French slang); 10) synchronous - diachronic; 11) intralinguistic interlingual [3, p. 450-451].

In our sample, a quantitative analysis of enantiosemic tokens demonstrates a sufficient number recorded in French vocabularies (Le Petit Robert (1)), linguistic enantiosemy is represented by the letter "A» that gives 56 examples of enantiosemy; 
letter «B» -102 examples; letter «C» -109 ; «D»- 43 [1]. Thus the analyzed matter shows not «pure», but speech enantiosemy. For example: agaçant -1) which is annoying; 2) seductive, embraceable; charmant - 1) charming, alluring; 2) unpleasant. That is, the denotative value often remains the same, and the evaluative or emotionally expressive connotation changes. Such enantiosemes are usually figurative and expressive, so they are often used in fiction, journalism, colloquial language and contribute to a pragmatic influence on the reader or interlocutor: que le diable te patafiole! 1) God bless you; 2) the hell with you! The anonymity meaning of the enantiosemic lexical unit is expressed through the context, but it is also removed through it. Often the commentary, the remark, the author's words that introduce the direct speech clarify the word meaning, so enantiosemy is not a serious problem for communication, since all lexical units are neutralized by the linguistic situation or the context.

Therefore, in our point of view, this linguistic phenomenon of our time is more considerably to be appropriated in abovementioned field, which requires careful linguistic research.

\section{References:}

1. Josette Rey-Debove (Ed.); Alain Rey (Ed.); Paul Robert (1985). Le petit Robert 1: dictionnaire alphabétique et analogique de la langue française [The Petit Robert: alphabetic and analogical dictionary of the French language]. Paris: Le Robert, $2171 \mathrm{p}$.

2. Shertsl, V. I. (1973). O slovakh s protivopolozhnymi znacheniyami (ili o tak nazyvaemoy enantiosemii) [About words with opposite meanings (or so-called enantiosemy)]. Khrestomatiya po istorii russkogo yazykoznaniya, pod red. F. P. Filina [Chretomathy on the history of Russian linguistics, edited by F. P. Filin]. Moscow: High School, pp. 259-264.

3. Smushchynska, I. V., Boiko, O. O. (2012). Enantiosemiia u suchasnii frantsuzkii movi: osnovni problemy [Enantiosemy in modern French: major problems]. Problems of semantics, pragmatics and cognitive linguistics, vol. 21, pp. 440-453.

\section{SUBSTANTIVATION AS THE MAIN MANIFESTATION OF THE MORPHOLOGICAL AND SYNTACTIC METHOD IN THE CREATION OF ZOONYMS}

\section{Svitlana Florinska ${ }^{1}$}

DOI: https://doi.org/10.30525/978-9934-588-11-2_47

Various aspects of the creation of onyms in a morphological and syntactic way have been explored over the last decades by such Ukrainian linguists: M. M. Torchynskyi [9], T. I. Poliarush [7], Gh. L. Arkushyn [1], S. L. Kovtiukh [5; 6], O. L. Kyryliuk [6] and other.

\footnotetext{
${ }^{1}$ Central Ukrainian State Pedagogical University named after V. Vynnychenko, Ukraine
} 